\title{
Itgb3-integrin-deficient mice may not be a sufficient model for patients with Glanzmann thrombasthenia
}

\author{
DONGYA LI ${ }^{1,2^{*}}$, JIE PENG $^{1 *}$, TIANTIAN LI ${ }^{1 *}$, YICHEN LIU $^{1}$, MIN CHEN $^{1}$ and XIAOFENG SHI ${ }^{1,3}$ \\ ${ }^{1}$ Department of Hematology, Affiliated Hospital of Jiangsu University, Zhenjiang, Jiangsu 212001; \\ ${ }^{2}$ Department of Hematology, First People's Hospital of Shangqiu, Shangqiu, Henan 476100; \\ ${ }^{3}$ Department of Hematology, The Second Affiliated Hospital of Nanjing Medical University, \\ Nanjing, Jiangsu 210011, P.R. China
}

Received June 30, 2020; Accepted January 27, 2021

DOI: $10.3892 / \mathrm{mmr} .2021 .12088$

\begin{abstract}
Itgb3-integrin-deficient (Itgb3 ${ }^{-/}$) mice have been reported as a Glanzmann thrombasthenia (GT) model and have been used for platelet research. However, it remains unclear whether this mouse model can fully simulate patients with GT or whether it has different characteristics from these patients. The present study aimed to answer this question. Itgb3 $3^{-/-}$mice were tested for platelet function, tail bleeding, whole-blood count, bone marrow hematopoiesis and organ enlargement. Itgb3 $3^{--}$platelets showed impaired functions, including fibrinogen binding, aggregation, adhesion or spreading. Itgb3 $3^{-1-}$ mice demonstrated decreased platelet count and microcytic hypochromic anemia. Reduced iron staining of bone marrow and decreased plasma ferritin level confirmed the diagnosis of iron deficiency anemia. Evident splenomegaly was observed in $\mathrm{Itgb3}^{-/-}$mice. Immunohistochemical analysis of spleen biopsy revealed normal expression of CD3 and CD19, but elevated expression of CD71, which suggested that the splenomegaly in Itgb3 $3^{-/}$mice may be associated with extramedullary hematopoiesis. In conclusion, Itgb3 $3^{-/}$mice exhibited some unique characteristics that differed from those of human patients with GT and thus cannot completely simulate patients with GT.
\end{abstract}

Correspondence to: Dr Xiaofeng Shi, Department of Hematology, The Second Affiliated Hospital of Nanjing Medical University, 121 Jiangjiayuan Road, Nanjing, Jiangsu 210011, P.R. China E-mail: shixiaofeng1977@163.com

*Contributed equally

Abbreviations: ADP, adenosine diphosphate; AF, Ala-Tyr-Pro-GlyLys-Phe(AYPGKF);CHM,chronichemorrhagicmodel;GT,Glanzmann thrombasthenia; Itgb3 ${ }^{-/}$, Itgb3-integrin-deficient; IDA, iron deficiency anemia

Key words: Itgb3-integrin-deficient mice, Glanzmann thrombasthenia, splenomegaly, extramedullary hematopoiesis, mouse model

\section{Introduction}

Platelet integrin $\alpha \mathrm{IIb} \beta 3$, also known as glycoprotein IIb/IIIa or CD41/CD61, is the most abundant membrane receptor on platelets $(1,2)$ and serves an important role in platelet function. There are $\sim 80,000-100,000$ receptors present on the surface of a resting platelet (3). An additional 20,000-40,000 receptors are found inside platelets, mainly in $\alpha$-granule membranes, but are also present in dense granules and the membranes lining the open canalicular system; platelet integrins are transported to the plasma membrane when platelets are activated and undergo release reaction (4-6). Allosteric changes in the $\alpha \mathrm{II} b \beta 3$ ectodomain are regulated by agonist-induced intracellular signals (known as inside-out signaling/activation), which enable platelets to bind to fibrinogen with high affinity (7). Upon binding to fibrinogen, $\alpha \operatorname{IIb} \beta 3$ transduces signals in an outside-in direction, mediating platelet spreading and stable adhesion (8). Some agonists, such as adenosine diphosphate (ADP), thrombin and collagen, can also activate $\alpha \operatorname{IIb} \beta 3$ by binding to their respective receptors (9). During this process, intracellular $\alpha \operatorname{IIb} \beta 3$ on $\alpha$-granule membrane is transferred to the membrane and its expression on the platelet surface will increase by $20-50 \%$ (10).

Qualitative or quantitative abnormalities of platelet integrin Itga2b $(\alpha \mathrm{IIb})$ and/or Itgb3 $(\beta 3)$ can cause Glanzmann thrombasthenia (GT), which is an inherited autosomal recessive hemorrhagic disorder characterized by a severe reduction in platelet aggregation in response to multiple physiologic agonists $(11,12)$. Itgb3 knockout homozygous $\left(\right.$ Itgb3 $\left.^{--}\right)$mice have been reported as a GT model and used for platelet research in past decades $(11,13)$, but their hematological characteristics and whether they can fully simulate patients with GT have not been fully elucidated. The present study aimed to answer these questions.

\section{Materials and methods}

Reagents. Phycoerythrin (PE)-conjugated hamster anti-CD61 (Itgb3) monoclonal antibody (cat. no. 553347) and PE/cyanine7 (CY7)-conjugated mouse anti-CD41 (Itga2b) antibody (cat. no. 133916) were purchased from BD Pharmingen (BD Biosciences) and Biolegend, Inc., respectively. Rabbit 
anti-CD3 monoclonal antibody (cat. no. MAB4841) was purchased from R\&D Systems China Co., Ltd. and rat anti-transferrin R (CD71) monoclonal antibody (8D3; cat. no. NB 100-64979-0.05mg) was purchased from Novus Biologicals, LLC. Rabbit anti-CD3e monoclonal antibody (cat. no. 99940S) was purchased from Cell Signaling Technology, Inc. Rat anti-CD19 antibody (1D3; cat. no. ARG55048) was purchased from Arigo Biolaboratories. Goat anti-rat IgG (H+L) HRP (cat. no. FMS-Rt01) for immunohistochemistry was purchased from Fcmacs Biotech Co., Ltd. Goat anti-rabbit IgG $(\mathrm{H}+\mathrm{L})$ HRP and DAB buffer kit (cat. no. RQ7100) for immunohistochemistry was purchased from Quanhui Imp and Exp Int'l Co., Ltd. Alexa-Fluor 647-conjugated human fibrinogen (cat. no. F35200) was purchased from Molecular Probes (Thermo Fisher Scientific, Inc.). Tetramethyl rhodamine isothiocyanate (TRITC)-conjugated phalloidin (cat. no. P1951) was purchased from Sigma-Aldrich (Merck KGaA). Rabbit anti-Itgb3 polyclonal antibody (cat. no. 4702) for western blotting was purchased from Cell Signaling Technology, Inc. Rabbit anti- $\beta$-actin polyclonal antibody (cat. no. 4968) for western blot was purchased from Cell Signaling Technology, Inc. HRP-conjugated goat anti-rabbit IgG secondary antibodies (cat. no. 5196-2504) was purchased from Bio-Rad, Laboratories, Inc. RIPA buffer (cat. no. 89900) and protease inhibitor mixture (cat. no. 87786) were purchased from Thermo Fisher Scientific, Inc. The 2X SDS Laemmli sample buffer (cat. no. S3401) was purchased from Sigma-Aldrich. ECL (cat. no. 1705070) was purchased from Bio-Rad, Laboratories, Inc. Collagen type I (cat. no. 385) and ADP (cat. no. 384) were purchased from Chrono-Log Corporation. Purified human fibrinogen (cat. no. FIB1) was purchased from Enzyme Research Labs Inc. Multimer purified human von Willebrand Factor (vWF; cat. no. HCVWF-0190) was purchased from Hematologic Technologies, Inc. Calcein AM (cat. no. C1430) was purchased from Thermo Fisher Scientific, Inc. D-phenylalanyl-L-prolyl-L-arginine chloromethyl ketone dihydrochloride (PPACK; cat. no. BML-P1117-0025) was purchased from Enzo Life Sciences, Inc. Arg-Gly-Asp-Ser (RGDS) peptide and the protease activated receptors 4 (PAR4)-thrombin receptor activating peptide, AF [Ala-Tyr-Pro-Gly-Lys-Phe (AYPGKF)], were synthesized at GL Biochem (Shanghai) Ltd. Mouse plasma ferritin (cat. no. JL11908) and mouse fecal occult blood test ELISA test kits (cat. no. JL50073) were purchased from Shanghai Jianglai Biological Technology Co., Ltd. All other biochemical reagents were obtained from Sigma-Aldrich (Merck KGaA).

Experimental animals. The Itgb3 ${ }^{-/}$C57BL/6 mice were received as a generous gift from Professor J. Liu (Shanghai Jiao Tong University School of Medicine, Shanghai, China). Wild-type $\left(\operatorname{Itgb} 3^{+/+}\right)$C57BL/6 mice were obtained from the Animal Experiment Center of Jiangsu University (Jiangsu, China). A total of $2 \mathrm{Itgb}^{-/}$male mice were mated with $2 \operatorname{Itgb}^{+/+}$female mice to obtain Itgb3 heterozygous ( $\left(\operatorname{tgb} 3^{+/-}\right.$) mice. Subsequently, Itgb3 $3^{-/}$male mice were mated with Itgb3 $3^{+/}$ female mice to obtain continuous offspring Itgb $3^{-/-}$mice. A total of 50 mice per group were used. The mice were housed (5 mice per cage) under a 12 -h light/dark cycle at $23^{\circ} \mathrm{C}$ in a specific-pathogen-free environment with ad libitum access to autoclaved food and water. The cages were changed each week.
Routine sanitation and environmental controls, including temperature, humidity (40-70\%), ventilation, illumination and light schedule and noise abatement, were performed by the animal care staff. Mice (age, 6-8 weeks; 1:1 male/female ratio) were used for each procedure with 3-10 mice/group. The animal study protocol was approved by the Jiangsu University Institutional Animal Care \& Use Committee (approval no. UJS-IACUC-AP-20190307021).

Blood collection and platelet preparation. Itgb $3^{-1-}$ mice (offspring) were identified by PCR according to previously published methods $(11,14)$. Whole blood containing the anticoagulant sodium citrate was collected by cardiac puncture from Itgb3 $3^{-/-}$mice following anesthetization with an intraperitoneal injection of $60 \mathrm{mg} / \mathrm{kg}$ pentobarbital sodium. Subsequently, $20 \mu \mathrm{l}$ of the blood was put aside for measurement of whole-blood count. The anesthetized mice were sacrificed by cervical dislocation after whole blood collection. Platelets were separated from whole blood by sequential centrifugation as previously described (14). The platelet suspensions were rested at room temperature for $1 \mathrm{~h}$ before being used for spreading assay, fibrinogen binding assay, adhesion assay and other experiments. Itgb3 ${ }^{+/+}$and/or Itgb3 $3^{+/}$mice served as controls.

Analysis of Itgb3 expression of Itgb3 ${ }^{-1-}$ platelets using flow cytometry. Briefly, $10 \mu 1$ whole blood containing the anticoagulant sodium citrate was collected from the Itgb3 ${ }^{+/+}$, Itgb3 ${ }^{+/}$and Itgb3 ${ }^{-/}$mice by tail cutting. The whole blood diluted in PBS was incubated with PE-conjugated hamster anti-CD61 (Itgb3) monoclonal antibody (1:100) and PE/CY7-conjugated mouse anti-CD41 (Itga2b) antibody (1:50) at room temperature for $30 \mathrm{~min}$. The expressions of Itga $2 \mathrm{~b}$ and Itgb3 in platelets were tested using flow cytometry ( $\mathrm{n}=3$ mice/group).

Analysis of Itgb3 expression of Itgb3 $3^{-/}$platelets using western blotting. Itgb $3^{-/-}$platelets $\left(1 \times 10^{8}\right)$ were lysed for $30 \mathrm{~min}$ at $4^{\circ} \mathrm{C}$ in ice-cold using RIPA buffer containing the protease inhibitor mixture to obtain proteins. Following centrifugation of the platelet lysate at $13,800 \mathrm{x}$ g for $15 \mathrm{~min}$ at $4^{\circ} \mathrm{C}$, the supernatant was added to an equal volume of $2 X$ SDS Laemmli sample buffer. The proteins from $1 \times 10^{8}$ platelets per mouse were dissolved in $200 \mu \mathrm{l}$ buffer, $10 \mu \mathrm{l}$ of which was loaded per lane. The proteins, after being boiled at $100^{\circ} \mathrm{C}$ for $5 \mathrm{~min}$, were separated by SDS-PAGE using 12\% gels and transferred to PVDF membranes. Membranes were blocked with 3\% BSA for $1 \mathrm{~h}$ at room temperature, then incubated with rabbit $\beta 3$ polyclonal antibody $(1: 1,000)$ or rabbit anti- $\beta$-actin polyclonal antibody $(1: 1,000)$ overnight at $4^{\circ} \mathrm{C}$ followed by HRP-conjugated goat anti-rabbit IgG secondary antibodies $(1: 10,000)$. Immunoreactive bands were detected by ECL. The Itgb3 $3^{+/}$and $\operatorname{Itgb} 3^{+/+}$mice served as controls ( $\mathrm{n}=3$ mice/group).

Analysis of soluble fibrinogen binding of Itgb3 ${ }^{-/}$platelets using flow cytometry. Soluble fibrinogen binding assay was performed as previously described (14). Briefly, $\left(1 \times 10^{6} / \mathrm{ml}\right)$ washed platelets from Itgb $3^{-/}$mice resuspended in HEPES-Tyrode's buffer (137.0 mM NaCl, $2.0 \mathrm{mM} \mathrm{KCl}, 12.0$

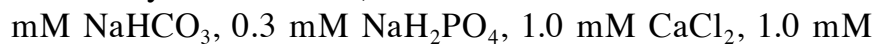
$\mathrm{MgCl}_{2}, 5.5 \mathrm{mM}$ glucose, 5.0 mM HEPES, 0.1\% BSA, pH 7.4) 
were divided into several groups and treated at $37^{\circ} \mathrm{C}$ for 30 min with agonists alone or co-treated with antagonists as follow: $\mathrm{Mn}^{2+}$ (presented by formation of $\mathrm{MnCl}_{2}$ ), $\mathrm{Mn}^{2+}+$ RGDS, ADP, ADP + RGDS, AF and AF + RGDS. The final concentration was $0.5 \mathrm{mM}$ for $\mathrm{Mn}^{2+}, 50 \mu \mathrm{M}$ for ADP, $0.5 \mathrm{mM}$ for AF peptide and $2 \mathrm{mM}$ for RGDS. Following stimulation, the platelets were incubated with $100 \mu \mathrm{g} / \mathrm{ml}$ of Alexa-Fluor 647-conjugated fibrinogen for $30 \mathrm{~min}$ at $37^{\circ} \mathrm{C}$ in the dark. The reaction was then stopped by fixation with $4 \%$ formaldehyde for $15 \mathrm{~min}$ at room temperature. Then the platelets were washed with PBS and centrifuged at $600 \mathrm{x}$ g for $5 \mathrm{~min}$ at room temperature. The Itgb3 ${ }^{+/+}$and Itgb3 ${ }^{+/-}$platelets were used as controls. Fibrinogen binding of platelets was tested using a flow cytometer (Beckman Coulter, Inc.) and the data were analyzed with FlowJo 7.6 software (FlowJo LLC). Specific fibrinogen binding was calculated by total binding minus nonspecific binding in the absence of any agonists ( $\mathrm{n}=3$ mice/group).

Aggregation of Itgb3 $^{-/-}$platelets. The assay was performed according to the instruction manual of the Chrono-log whole blood lumi-aggregometer (Chrono-log Corporation). Briefly, blood containing $3.8 \%$ sodium citrate from $\mathrm{Itgb}^{-/}$mice by cardiac puncture was collected and diluted $1: 1$ in physiological saline. Platelet aggregation was measured at $37^{\circ} \mathrm{C}$ in whole blood lumi-aggregometer (Chrono-log Corporation) using electrical impedance following the addition of $2 \mathrm{U} / \mathrm{ml}$ thrombin, $6 \mu \mathrm{g} / \mathrm{ml}$ collagen or $12 \mu \mathrm{g} / \mathrm{ml}$ collagen. An AC voltage in the millivolt range is applied to the probe circuit. During a brief period of equilibration, a monolayer of platelets forms on the exposed portions of the wires, resulting in a stable baseline of impedance which is assigned a value of zero ohms of resistance. Then, $20.0 \pm 0.2 \mathrm{ohms}$ were added to the impedance baseline and the gain was adjusted, so that $20 \mathrm{ohms}$ equals $50 \%$ of scale. Aggregation was recorded for $14 \mathrm{~min}$. Itgb3 $^{+/-}$and Itgb3 ${ }^{+/+}$mice served as controls ( $\mathrm{n}=3$ mice/group).

Thrombus formation of Itgb3 ${ }^{-/}$platelets under flow. Thrombus formation of Itgb3 $3^{-/}$platelets under flow was performed as previously described (14). Briefly, $100 \mu \mathrm{g} / \mathrm{ml}$ collagen was perfused at a shear rate of $125 \mathrm{~s}^{-1}$ ( $5 \mathrm{dynes} / \mathrm{cm}^{2}$ for shear stress) for 2 min through the Bioflux 200 microfluidic channels (Fluxion Biosciences, Inc.) to coat the channels at $4^{\circ} \mathrm{C}$ overnight, followed by blocking with $2 \% \mathrm{BSA}$ at room temperature for $1 \mathrm{~h}$. The PPACK- anticoagulant whole blood (without sodium citrate) collected from Itgb3 $3^{-/}$mice through cardiac puncture was labeled with the fluorescence dye, Calcein AM, and perfused at a shear rate of $1,500 \mathrm{~s}^{-1}$ for $10 \mathrm{~min}$ through the microfluidic channels. The process of thrombus formation was recorded by a video using NIS D image software version 3.1 (Nikon Corporation) and Bioflux 200 software. Itgb3 $3^{+/}$and Itgb3 ${ }^{+/+}$mice served as controls ( $\mathrm{n}=3 \mathrm{mice} /$ group).

Adhesion and spreading of Itgb3 ${ }^{-/-}$platelets. For the adhesion assays, a 96-well plate was coated with $20 \mu \mathrm{g} / \mathrm{ml}$ fibrinogen, $4 \mu \mathrm{g} / \mathrm{ml}$ collagen, or $4 \mu \mathrm{g} / \mathrm{ml} \mathrm{vWF}$ at $4^{\circ} \mathrm{C}$ overnight and then blocked with $2 \% \mathrm{BSA}$ at room temperature for $1 \mathrm{~h}$. Washed platelets $\left(1 \times 10^{6} / \mathrm{ml}\right)$ from Itgb3 ${ }^{-/-}$mice were allowed to adhere for $1 \mathrm{~h}$ at $37^{\circ} \mathrm{C}$. Next, the wells were rinsed with PBS to remove non-adherent or unstable adherent platelets. 4-Nitrophenylphosphate (PNPP) was used to quantify the adherent platelets. In detail, the buffer (1\% Triton X-100,
$3 \mathrm{mg} / \mathrm{ml}$ PNPP, $100 \mathrm{mM}$ sodium acetate, $\mathrm{pH}$ 5.0) was added and incubated at $37^{\circ} \mathrm{C}$ for $1 \mathrm{~h}$. Then, sodium hydroxide $(0.5 \mathrm{M})$ was added to stop the reaction. The optical density (OD) value was read at a wavelength of $405 \mathrm{~nm}$ using a microplate reader. Washed Itgb3 $3^{+/+}$platelets were used as a control.

Platelet spreading assays were performed as previously described (14). Briefly, the chamber slides were coated with $20 \mu \mathrm{g} / \mathrm{ml}$ fibrinogen overnight at $4^{\circ} \mathrm{C}$ and then blocked with $2 \%$ BSA. Washed platelets $\left(2 \times 10^{5} / \mathrm{ml}\right)$ resuspended in HEPES-Tyrode's buffer were allowed to adhere and spread on fibrinogen-coated slides at $37^{\circ} \mathrm{C}$ for $2 \mathrm{~h}$. After washing three times with PBS, the attached platelets were fixed with $4 \%$ paraformaldehyde for $15 \mathrm{~min}$ at room temperature, permeabilized with $0.2 \%$ Triton X-100 and stained with TRITC-conjugated phalloidin as previously described (15). Itgb3 $3^{+/+}$platelets were used as a control. The coverage area of spreading was measured using ImageJ software version 1.4.3.67 (National Institutes of Health). A total of five randomly selected fields from different tests were used for statistical analysis $(n=3$ mice analyzed from each group).

Tail bleeding time. Itgb3 $3^{-/-}$mice were anesthetized with intraperitoneal injection of $60 \mathrm{mg} / \mathrm{kg}$ pentobarbital sodium. A $3-\mathrm{mm}$ section was cut from the tail tip in 6-week-old mice and then the bleeding time was counted. Every $30 \mathrm{sec}$ the wounded tails were touched to a filter paper to confirm whether the bleeding had stopped or not. The maximum time for counting was $30 \mathrm{~min}$. Itgb3 $3^{+/-}$and Itgb3 $3^{+/+}$mice served as controls. Simultaneously, blood smear slides were made from the cut tail followed by Wright's staining at room temperature for $15 \mathrm{~min}$ ( $\mathrm{n}=10 \mathrm{mice} / \mathrm{group}$ ).

Establishment of chronic hemorrhagic model (CHM) mice. A total of 38 -week-old male Itgb3 ${ }^{+/+}$mice were anesthetized with intraperitoneal injection of $60 \mathrm{mg} / \mathrm{kg}$ pentobarbital sodium in accordance with animal welfare standards. Mice were restrained and the neck gently pressed to cause head vein congestion. A sterilized capillary pipette was gently pressed into the posterior orbital venous plexus. The blood was naturally sucked into the tube. After the required blood had been obtained, the pressure on the neck was removed and the blood collection tube was pulled out at the same time to prevent postoperative bleeding from the puncture hole and sterile gauze or cotton ball was used to compress the eyeball to stop bleeding. During the operation, a veterinarian was nearby to observe the breathing and palpate heart rate. Following the operation, $0.4 \mathrm{ml}$ of $0.9 \%$ sodium chloride was given through gavage twice to add fluid to prevent shock in accordance with animal welfare standards. The animal was covered with insulation blanket to keep it warm. The animal was placed in a cage in warm environment after awakening. Blood $(0.5 \mathrm{ml})$ was collected every time and twice a week. After 1 month, CHM mice were established successfully, and three CHM mouse models were established. A total of 38 -week-old male Itgb3 $3^{+/+}$ mice without treatment served as controls. The animals were kept individually, as aforementioned, and monitored daily during the $\mathrm{CHM}$ induction for animal welfare.

Bone marrow smear and spleen biopsy of Itgb3 $3^{-/-}$mice. Itgb3 $3^{-1-}$ mice were sacrificed after anesthetization with pentobarbital 
sodium injection by cervical dislocation and their organs, including the spleen, heart, kidneys and liver were collected and weighed. Mouse femurs were dissected with a scissor. Muscles and connective tissues were removed as thoroughly as possible. The cartilages on both end of the femur were removed. The marrow of femurs was leaked out and prepared for bone marrow smear. Wright staining and iron staining (Prussian Blue) at room temperature for 20 min were performed on bone marrow smears. Itgb3 $3^{+/}$, Itgb3 $3^{+/}$and $\mathrm{CHM}$ mice served as controls ( $\mathrm{n}=10$ mice/group).

Immunohistochemistry of spleen biopsies from Itgb3 $3^{--}$mice. Half of the spleens collected from Itgb $3^{+/+}$and Itgb3 $3^{-/}$mice were fixed in $10 \%$ formalin overnight at room temperature and subsequently embedded in paraffin. The other half of the spleens were embedded in optimal cutting temperature compound and sectioned $(1 \mathrm{~mm})$ at low temperatures and fixed with precooled acetone to make the frozen section. The spleen tissue sections were stained sequentially with hematoxylin and eosin at room temperature for 2-3 min. The immunohistochemical procedure was performed on paraffin sections or frozen sections according to a previous study (16). The slides were incubated with monoclonal anti-CD3 (1:50), anti-CD19 (1:200) or anti-CD71 (1:100) antibodies at $4{ }^{\circ} \mathrm{C}$ overnight followed by goat anti-rat $\operatorname{IgG}(\mathrm{H}+\mathrm{L}) \mathrm{HRP}(1: 1,000)$ or goat anti-rabbit IgG $(\mathrm{H}+\mathrm{L}) \operatorname{HRP}(1: 1,000)$ at $37^{\circ} \mathrm{C}$ for $1 \mathrm{~h}$ and diaminobenzidine substrate with hematoxylin counterstaining ( $\mathrm{n}=3$ mice/ group). The slides were observed under a light microscope (Olympus BX53F; Olympus Corporation) with Smart V digital camera and analyzed using JD-801 Image analysis system (JEDA Science-Technology Development Co., Ltd.).

The concentration of plasma ferritin from Itgb3 ${ }^{-1}$ mice. Whole blood containing the anticoagulant sodium citrate was collected by cardiac puncture from Itgb $3^{-/}$mice after anesthetization as aforementioned. Then plasma was obtained by centrifugation at $1,000 \mathrm{x} \mathrm{g}$ for $30 \mathrm{~min}$ at room temperature. Plasma ferritin was tested using a ferritin ELISA test kit following the manufacturer's protocol. Itgb $3^{+/+}$mice served as controls ( $\mathrm{n}=8 \mathrm{mice} / \mathrm{group}$ ).

Fecal occult blood test of Itgb3 $3^{-/}$mice. Feces from Itgb3 $3^{-/}$mice were collected then were tested using fecal occult blood ELISA test kit (Shanghai Jianglai Biological Technology Co., Ltd.) following the manufacturer's protocol. Itgb $3^{+/+}$mice served as controls ( $\mathrm{n}=8 \mathrm{mice} /$ group).

Statistical analysis. SPSS version 18 (SPSS, Inc.) was used for statistical analysis. Quantitative data were expressed as the mean \pm standard deviation. Differences between two groups were assessed using Student's t-test. For datasets containing three or more groups, one-way ANOVA followed by Tukey's test was used. $\mathrm{P}<0.05$ was considered to indicate a statistically significant difference.

\section{Results}

Genotyping and platelet Itgb3 expression of Itgb $3^{-/}$mice. DNA was extracted from the tail tissue of $\operatorname{Itgb} 3^{+/+}$, Itgb $^{+/-}$and Itgb3 $3^{-1-}$ mice and then genotyped by PCR. A band of $538 \mathrm{bp}$ was observed for Itgb3 $3^{-/-}$mice, $446 \mathrm{bp}$ for Itgb $3^{+/+}$mice and double bands for Itgb3 ${ }^{+/}$mice (Fig. S1A). Western blotting results showed no Itgb3 protein expression in washed Itgb3 $3^{-/}$platelets (Fig. S1B). Whole-blood from Itgb3 $3^{+/}$, Itgb3 $3^{+/-}$and Itgb3 $3^{-/-}$mice were incubated with PE-conjugated anti-CD61 (Itgb3) antibody and $\mathrm{PE} / \mathrm{CY} 7-$ conjugated anti-CD41 (Itga2b) antibody and then subjected to flow cytometry. Almost no Itga2b and Itgb3 was expressed on the Itgb3 $3^{-/}$platelet surface, compared with that on the Itgb $3^{+/-}$and Itgb3 $3^{-/}$platelet surface (Fig. S1C-E).

Soluble fibrinogen binding of Itgb3 $3^{-/}$platelets. The washed Itgb3 $3^{+/+}$platelets can bind to soluble fibrinogen under the stimulation of $\mathrm{Mn}^{2+}$, ADP or AF peptide, which can be partially inhibited by co-treatment with the antagonist RGDS peptide (Fig. 1A). The fibrinogen binding of Itgb3 $3^{+-}$platelets was similar to that of Itgb $3^{+/+}$platelets. However, the Itgb3 ${ }^{-/}$platelets did not bind to soluble fibrinogen under the stimulation of any agonists.

Aggregation of Itgb3 $3^{-/}$platelets. Electronic resistance mediated by platelet aggregation from Itgb $3^{+/+}$mice was $8 \mathrm{ohms}$ induced by $2 \mathrm{U} / \mathrm{ml}$ thrombin, $10 \mathrm{ohms}$ induced by $6 \mu \mathrm{g} / \mathrm{ml}$ collagen and $11 \mathrm{ohms}$ induced by $12 \mu \mathrm{g} / \mathrm{ml}$ collagen, whereas that from Itgb3 ${ }^{-/}$mice was 2, 0 and 2 ohms, respectively (Fig. 1B).

Thrombus formation of Itgb3 ${ }^{-/}$platelets under flow. On a collagen-coated surface at shear rates of $1,500 \mathrm{~s}^{-1}$, the thrombus formed from Itgb $3^{+/+}$mice was large and thick, showing strip-shaped distribution along the direction of blood flow (Fig. 1C and D). By contrast, the thrombus formed from Itgb $3^{--}$mice was scattered, thin and easily washed off.

Adhesion and spreading of Itgb3 $3^{--}$platelets. The adhesion of washed Itgb $3^{--}$platelets was notably lower on the fibrinogen or collagen-coated surface compared with that of washed Itgb $3^{+/+}$platelets, no difference was observed in the adhesion on the vWF-coated surface (Fig. 2A and B). The Itgb3 $3^{+/+}$ platelets spread well on the fibrinogen-coated surface with the regular actin arrangement. On the surface without any matrix (control), Itgb3 ${ }^{+/+}$platelets also spread, but the actin arrangement was disordered and diffuse. However, the spreading of Itgb3 $3^{-/}$platelets on fibrinogen-coated surface and control was notably impaired (Fig. 2C and D).

Spontaneous hemorrhage and anemia in Itgb3 $3^{-/}$mice. Itgb3 $3^{-1-}$ mice exhibited prolonged bleeding time (Fig. 3A and B) after tail cutting and they were more prone to subcutaneous hemorrhage (Fig. 3C) at birth compared with Itgb3 $3^{+/+}$ mice. Itgb3 ${ }^{-1-}$ mice had a mean red blood cell count of $6.38 \pm 2.02 \times 10^{12}$ cells/l, hemoglobin of $89.38 \pm 25.73 \mathrm{~g} / 1$ and a platelet count of $536.18 \pm 195.58 \times 10^{9}$ cells/l, which were lower compared with Itgb3 $3^{+/+}$mice (Table I). Wright staining showed increased microcytic hypochromic erythrocytes in peripheral blood smear from Itgb3 ${ }^{-/}$mice compared with that from Itgb3 $3^{+/+}$mice (Fig. 3D).

Increased erythroblasts and extramedullary hematopoiesis in Itgb $3^{-1}$ mice. The bone marrow smears of Itgb $3^{-/}$mice exhibited significantly more early erythroblasts compared with Itgb3 $3^{+/+}$ mice (Fig. 4A and B), and the Itgb $3^{-/-}$mice exhibited a relatively 

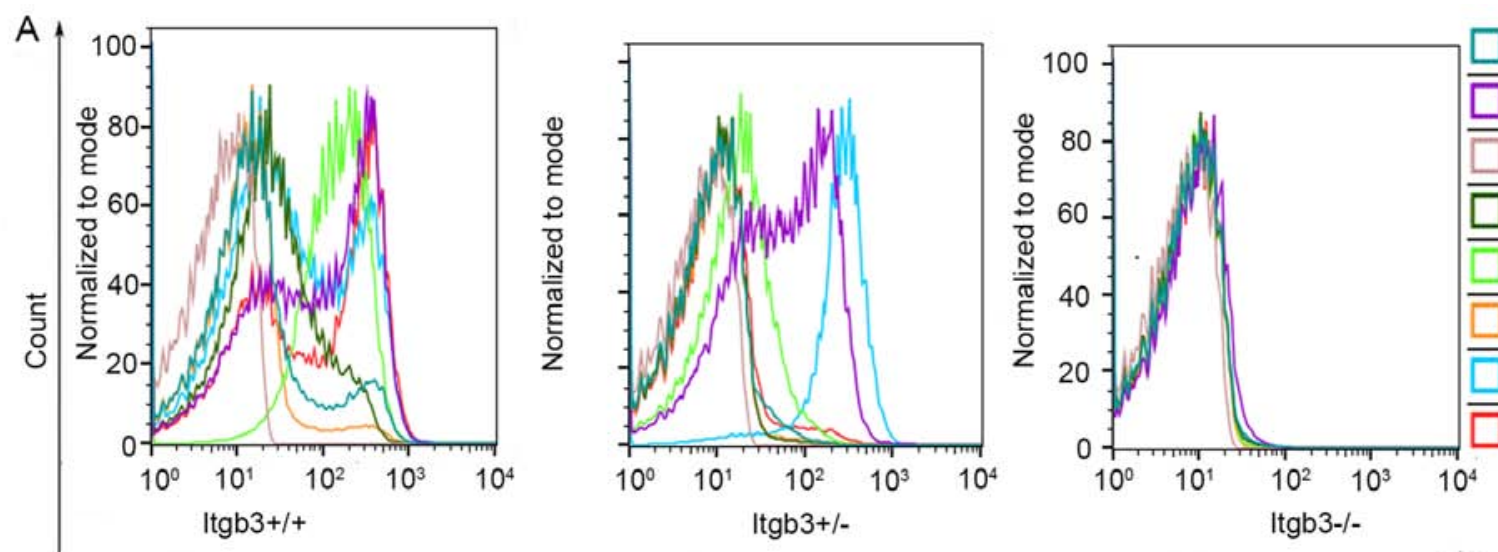

$A D P+R G D S$ $A F+R G D S$ Blank $\mathrm{Mn}^{2+}+\mathrm{RGDS}$ $\mathrm{Mn}^{2+}$ Fib AF ADP

Fibrinogen binding

B
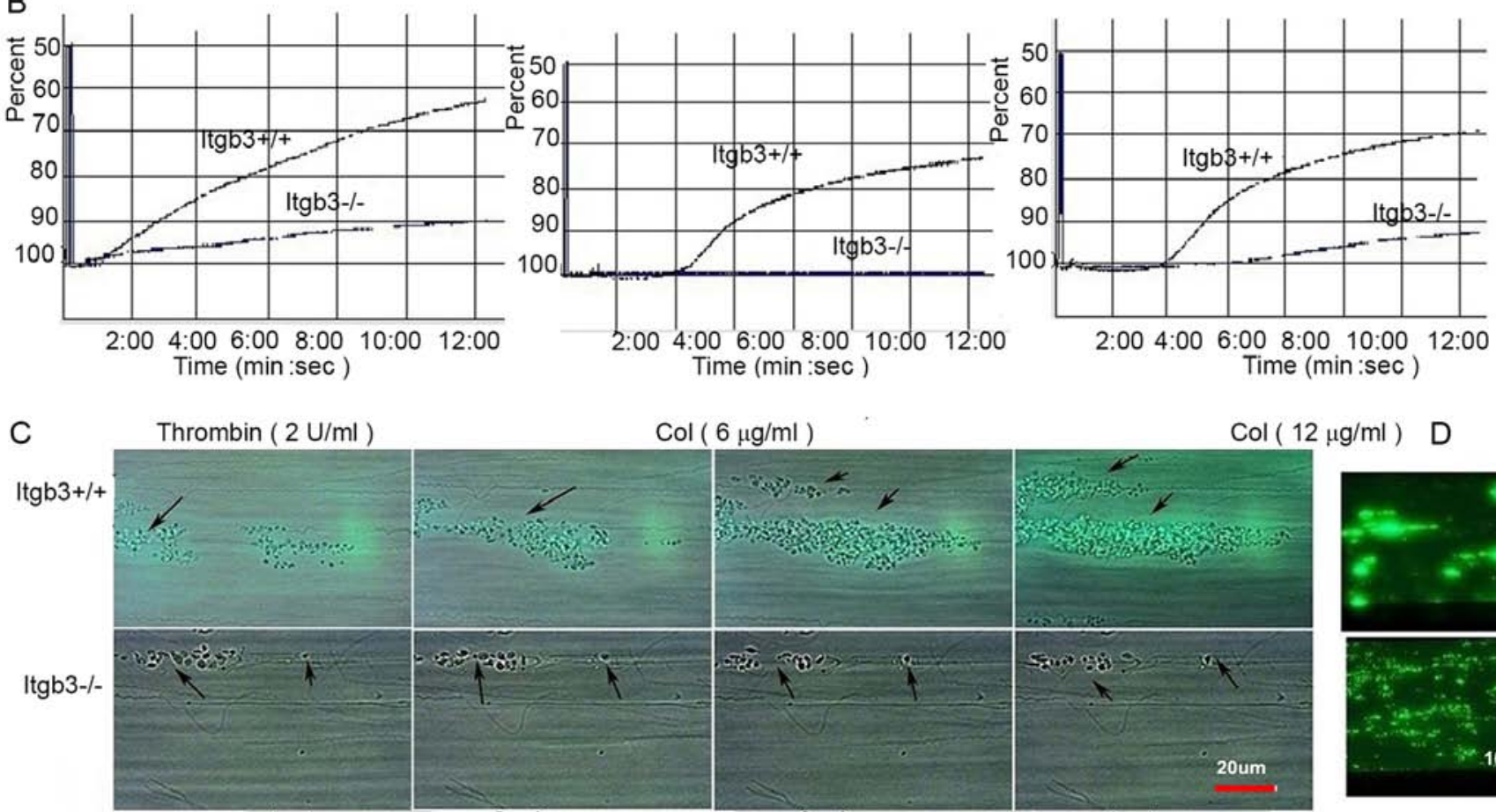

$1 \mathrm{~min}$

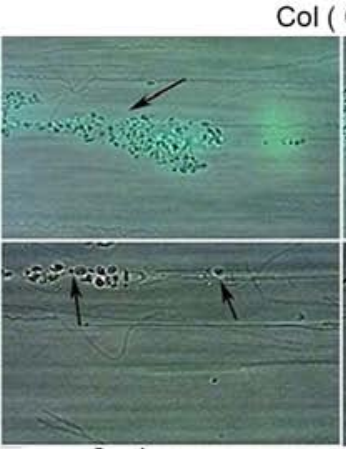

$\mathrm{Col}(6 \mu \mathrm{g} / \mathrm{ml})$
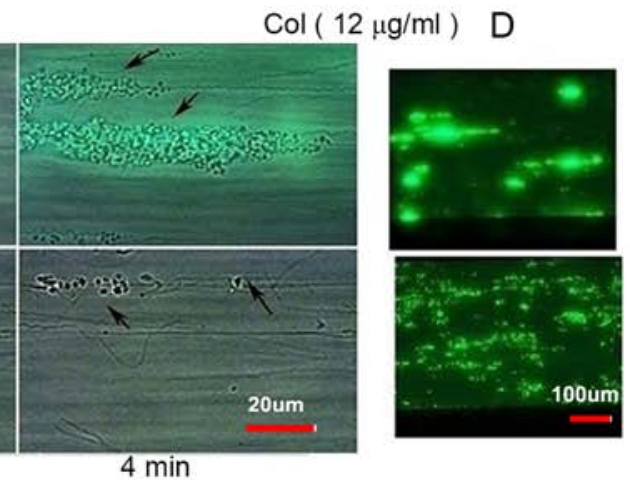

Figure 1. Fibrinogen binding and aggregation of Itgb3 $3^{-/}$platelets. (A) Fibrinogen binding of washed platelets from three types of mice $\left(\right.$Itgb3 $3^{+/+}$, Itgb3 $3^{+/}$and $\mathrm{Itgb}^{-/}$mice) under stimulation by agonists, including $\mathrm{ADP}, \mathrm{AF}$, or $\mathrm{Mn}^{2+}$, with or without the inhibitor RGDS. (B) Whole blood aggregation of Itgb3 ${ }^{+/ /}$and Itgb3 $^{-/}$mice under stimulation of $2 \mu \mathrm{g} / \mathrm{ml}$ thrombin, $6 \mu \mathrm{g} / \mathrm{ml}$ collagen or $12 \mu \mathrm{g} / \mathrm{ml}$ collagen. Calcein AM-labeled whole blood from Itgb3 ${ }^{+/+}$mice and Itgb3 $3^{-/}$ mice was perfused over a collagen-coated surface at shear rates of $1,500 \mathrm{~s}^{-1}$ and images were captured under (C) bright-field at the indicated time points and (D) fluorescence microscope at $4.5 \mathrm{~min}$. Arrows indicated the adhered platelets. ADP, adenosine diphosphate; AF, Ala-Tyr-Pro-Gly-Lys-Phe (AYPGKF); Itgb3, integrin $\beta 3$; RGDS, Arg-Gly-Asp-Ser.

lower amounts of iron granules compared with $\mathrm{Itgb}^{+/+}$mice, indicating iron deficiency in Itgb $3^{-/}$mice (Fig. 4C). Enlarged spleens were observed in Itgb3 $3^{-/-}$mice (Fig. 4D). The ratio of spleen to whole body weight was higher in $\mathrm{Itgb}^{-/-}$mice than in Itgb $3^{+/+}$mice suggesting a splenomegaly in Itgb3 $3^{-1-}$ mice (Fig. 5A). CHM mice were established to confirm whether CHM also exhibits splenomegaly and to determine whether the splenomegaly in Itgb $^{-/-}$mice is a result of chronic bleeding (Fig. 5B). Immunohistochemical staining of spleen biopsies from Itgb3 $3^{-/}$mice showed no change in the expression of CD3 and CD19, which are the markers of $\mathrm{T}$ lymphocytes and B lymphocytes, respectively, whereas the expression of CD71, which is a marker of erythrocytes, increased compared with Itgb $3^{+/+}$mice (Fig. 5C and D).

Decreased level of plasma ferritin in in Itgb3 $3^{-/}$mice. Itgb3 $3^{-1-}$ mice had significantly lower level of plasma ferritin compared with Itgb3 $3^{-1-}$ mice (Fig. 5E). There was no difference of fecal occult blood between Itgb3 $3^{+/+}$mice and Itgb3 $3^{-/}$mice (Fig. 5F).

\section{Discussion}

Platelet integrin Itgb3 subunit is a cell-surface receptor that mediates cell-cell and cell-matrix interactions (17). Integrin 


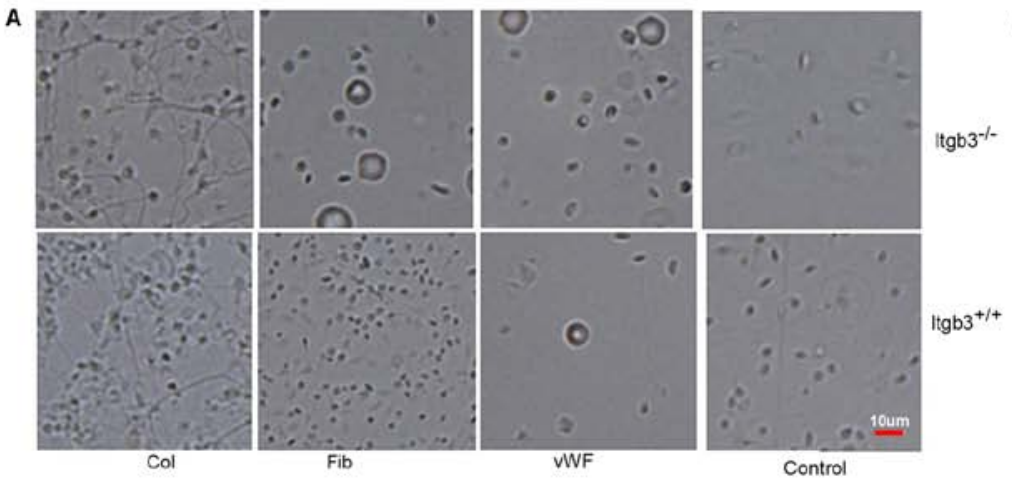

B

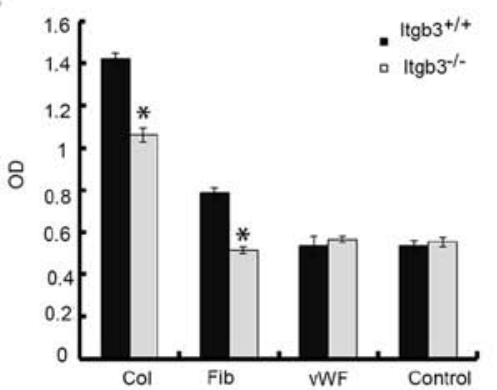

c

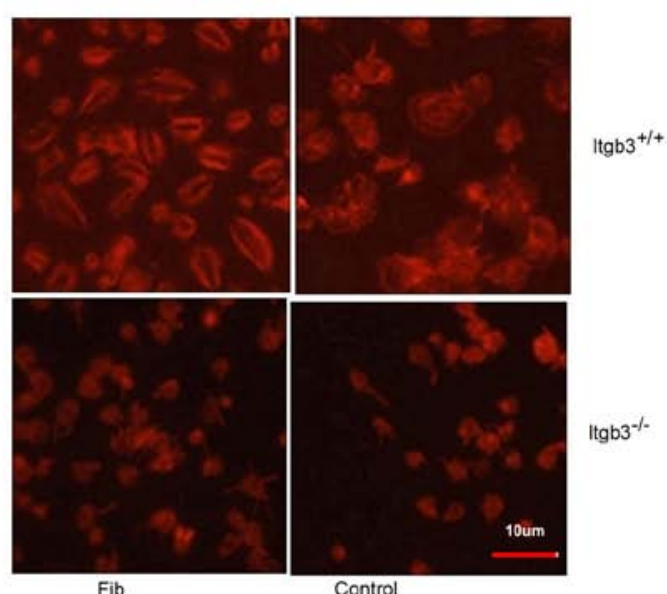

Fib

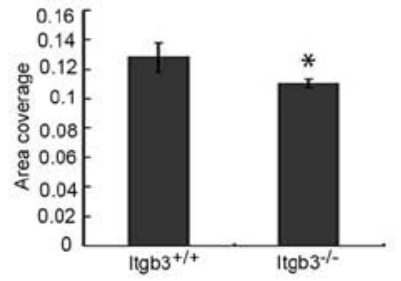

Figure 2. Adhesion and spreading of Itgb3 $3^{-/}$platelets. (A) Adhesion of washed Itgb3 ${ }^{+/+}$and Itgb $3^{-/}$platelets on the surfaces coated with Col, Fib, vWF or blank control. (B) Quantification of adhered platelets in (A). (C) Spreading of washed Itgb3 ${ }^{+/+}$and Itgb3 $3^{-/}$platelets on immobilized fibrinogen or control. TRITC-conjugated phalloidin was used to label actin (red). (D) Area coverage of spreading of washed Itgb $3^{+/+}$and Itgb3 $3^{-/}$platelets on immobilized fibrinogen in $(\mathrm{C}) .{ }^{*} \mathrm{P}<0.05$ vs. Itgb3 ${ }^{+/+}$. Col, collagen; Fib, fibrinogen; Itgb3, integrin $\beta 3$; vWF, von Willebrand Factor.

A

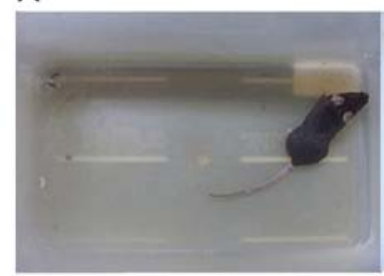

$\operatorname{ltgb} 3^{+1+}$

C

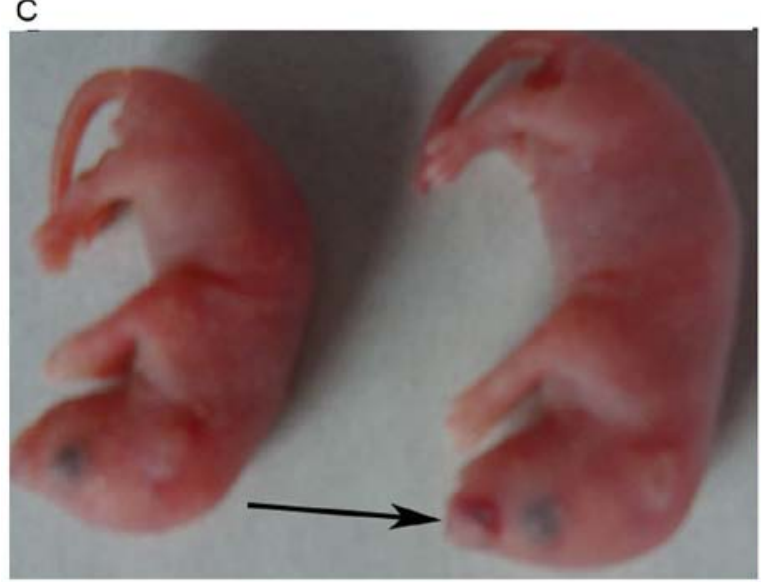

$\operatorname{ltgb} 3^{+/+}$
Itgb3-/-
B

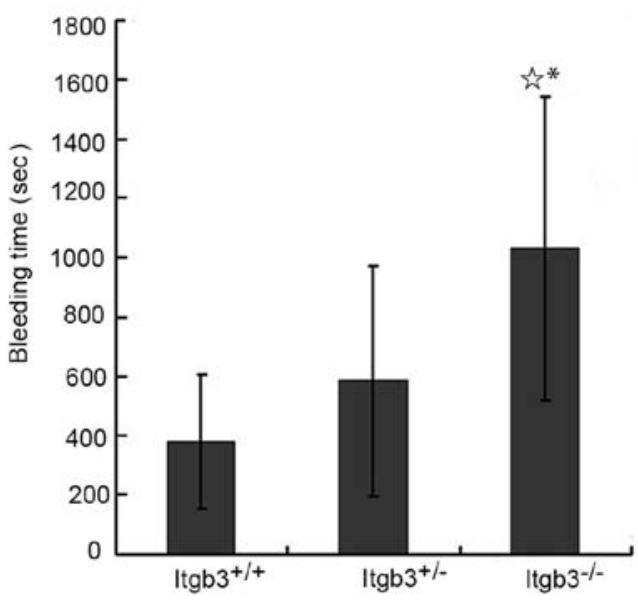

D

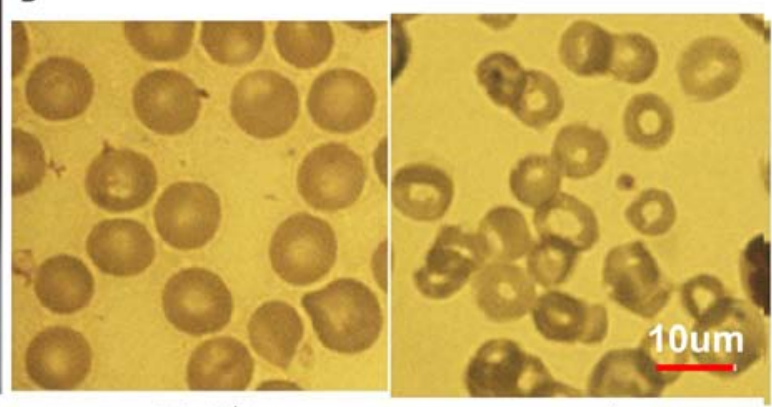

$\operatorname{ltgb} 3^{+/+}$
Itgb3-/-

Figure 3. Bleeding time and blood smear of Itgb3 $3^{-/}$mice. (A) Bleeding of Itgb3 $3^{+/+}$and Itgb3 $3^{-/-}$mice 8 min after tail cutting. Note the blood stains on the bottom of cage in Itgb3 $3^{-/-}$mouse group. (B) Bleeding time of different types of mice, ${ }^{*} \mathrm{P}<0.05 \mathrm{vs}$. Itgb3 ${ }^{+/+}$mice; ${ }^{\text {th}} \mathrm{P}<0.05 \mathrm{vs}$. Itgb3 ${ }^{+/-}$mice. (C) Subcutaneous hemorrhage in a Itgb3 $3^{-/}$newborn pup. Arrow indicates the site of bleeding). (D) Wright staining of peripheral blood smear of Itgb3 ${ }^{-/-}$mice and Itgb3 $3^{+/+}$mice. Note the microcytic hypochromic erythrocytes from Itgb3 ${ }^{-/-}$mice. 
Table I. Whole blood count of different groups of mice.

\begin{tabular}{lcccc}
\hline Group & Wbc, $\times 10^{12} / 1$ & Rbc, $\times 10^{12} / 1$ & Hb, g/l & Plt, x $10^{9} / 1$ \\
\hline Itgb3 $^{+/+}$ & $5.86 \pm 5.17$ & $9.38 \pm 1.54$ & $123.1 \pm 24.86$ & $1031.27 \pm 418.26$ \\
Itgb3 $^{+/-}$ & $7.73 \pm 7.80$ & $10.44 \pm 2.40$ & $140.35 \pm 33.69$ & $1112.58 \pm 356.91$ \\
Itgb3 $^{-/-}$ & $4.40 \pm 3.58$ & $6.38 \pm 2.02^{\mathrm{a}, \mathrm{b}}$ & $89.38 \pm 25.73^{\mathrm{a}, \mathrm{b}}$ & $536.18 \pm 195.28^{\mathrm{a}, \mathrm{b}}$ \\
\hline
\end{tabular}

${ }^{\mathrm{a}} \mathrm{P}<0.05$ vs. Itgb3 ${ }^{+/+}$mice; ${ }^{\mathrm{P}}<0.05$ vs. Itgb3 ${ }^{+/-}$mice. Wbc, white cell count; Rbc, red blood count; Hb, hemoglobin; Plt, platelet count; Itgb3, integrin $\beta 3$.

A

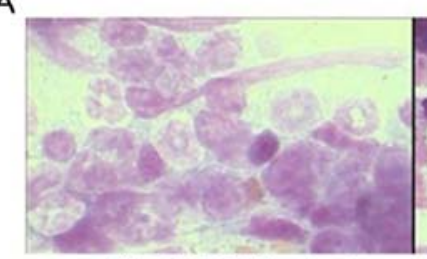

Itgb3 ${ }^{+/+}($x100 Objective $)$

C

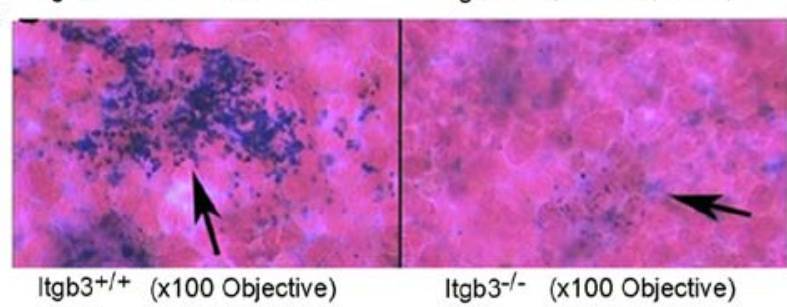

B

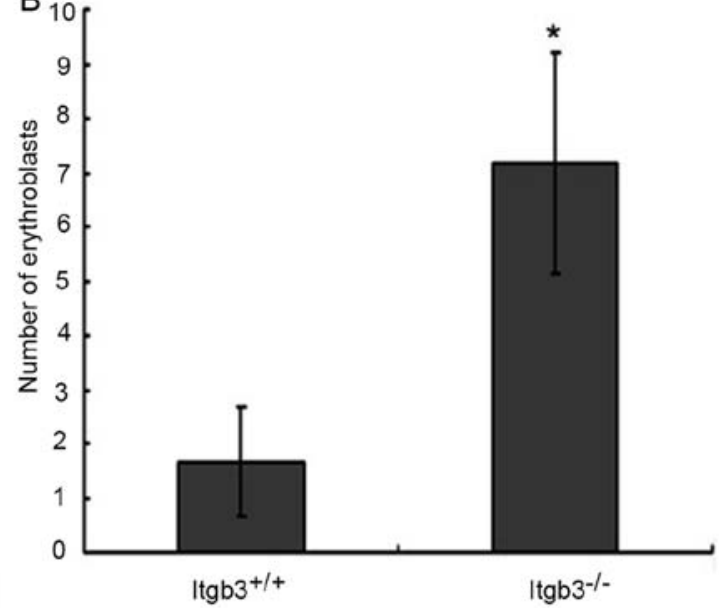

$\operatorname{ltgb} 3^{+/+}$

$\operatorname{ltg} 3^{-/-}$

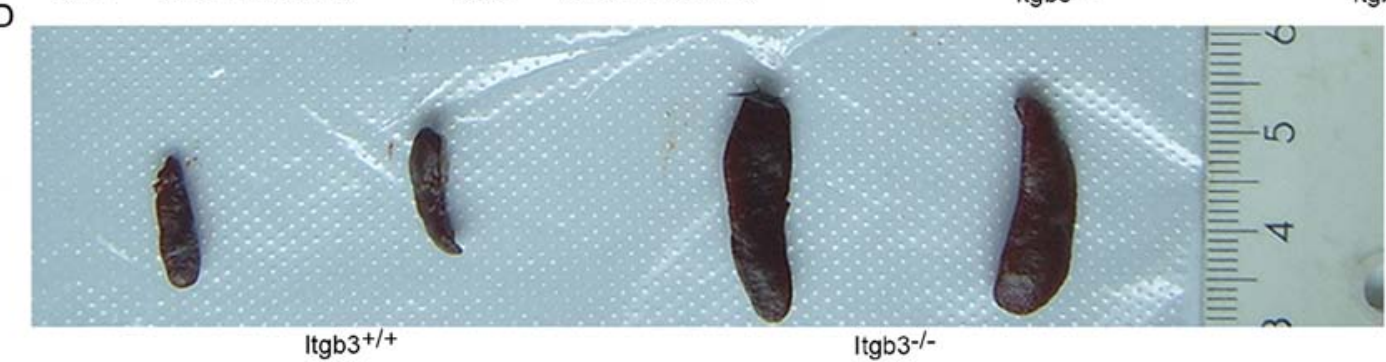

Figure 4. Bone marrow and spleen of Itgb3 ${ }^{-/}$mice. (A) Clustered erythroblasts are shown in bone marrow smear (Wright staining) from Itgb3 $3^{-/}$mice (arrows) Magnification, $x 1,000$. (B) The number of erythroblasts increased in Itgb3 ${ }^{-/}$compared with those in Itgb3 $3^{+/+}$mouse bone marrow. Average number of erythroblasts in every 5 fields. $\mathrm{n}=3$; ${ }^{*} \mathrm{P}<0.05 \mathrm{vs}$. Itgb3 $3^{+/+}$mice. (C) Prussian blue staining shows decreased iron granules (arrows) in Itgb3 ${ }^{-/ /}$bone marrow vs. Itgb3 ${ }^{+/+}$ bone marrow. Magnification, $x 1,000$. (D) Itgb3 ${ }^{-/}$mice exhibited larger spleens compared with Itgb3 ${ }^{+/+}$mice. Itgb3, integrin $\beta 3$.

Itgb3 $(\beta 3)$ subunit binds with Itga2b $(\alpha \mathrm{II})$ to form integrin $\alpha \operatorname{IIb} \beta 3$, which is the most abundant receptor on the platelet surface (2). Qualitative or quantitative abnormalities of the platelet integrin $\alpha \mathrm{IIb}$ and Itgb3 can cause GT (18), an inherited hemorrhagic disorder (19). The incidence is $\sim 1$ in $1,000,000$; the highest incidence rate is 6 in 700 in the Iraqi-Jewish population where consanguineous mating is common (20). Patients with GT show defects in platelet aggregation and clot retraction, as well as prolonged bleeding times $(21,22)$. Thus far, $\sim 50$ specific gene mutations in Itgb3 or $\alpha \mathrm{IIb}$ are known (23). Itgb3 ${ }^{-/-}$ mice were generated as a GT model in 1999 (11) and have been used widely in recent decades on platelet research. However, it is unclear whether this mouse model can fully simulate patients with GT; moreover, the hematological characteristics of this model have not been fully described. Therefore, the present study investigated the characteristics of Itgb3 $3^{-/-}$mice.

Platelets from Itgb3 $3^{--}$mice did not express Itgb3 and $\alpha \mathrm{IIb}$. Integrin Itgb3 and $\alpha \mathrm{IIb}$ can form a complex that protects glycoproteins from proteolytic digestion; thus, if either integrin $\alpha \mathrm{IIb}$ or Itgb3 is absent or unable to form a normal complex, the other subunit will be rapidly degraded (24). The inability of Itgb3 $3^{-/}$platelets to bind to fibrinogen under the stimulation of agonists, including $\mathrm{M}^{\mathrm{n} 2+}$ (which directly acts on the extracellular segment of $\alpha \operatorname{IIb} \beta 3$ ), ADP (which binds to $\mathrm{P} 2 \mathrm{Y} 12$ or $\mathrm{P} 2 \mathrm{Y} 1$ receptors), or AF peptide (which binds to thrombin receptor) (25-27), confirmed the important role of $\alpha \mathrm{IIb} \beta 3$ in fibrinogen binding. The aggregation of platelets is the connection of a platelet to another platelet through its $\alpha \operatorname{IIb} \beta 3$ receptor binding to fibrinogen. Therefore, Itgb3 $3^{-/}$platelets rarely aggregate under the stimulation of collagen or thrombin, nor on a collagen-coated surface under flow. The adhesion of Itgb3 ${ }^{-/}$platelets was impaired on the fibrinogen-coated surface and partially inhibited on the collagen-coated surface. The adhesion of platelets to collagen is complex. $\alpha 2 \beta 1$ and GPVI on the surface of platelets can bind to collagen, which triggers the inside out signaling pathway leading to the activation of 

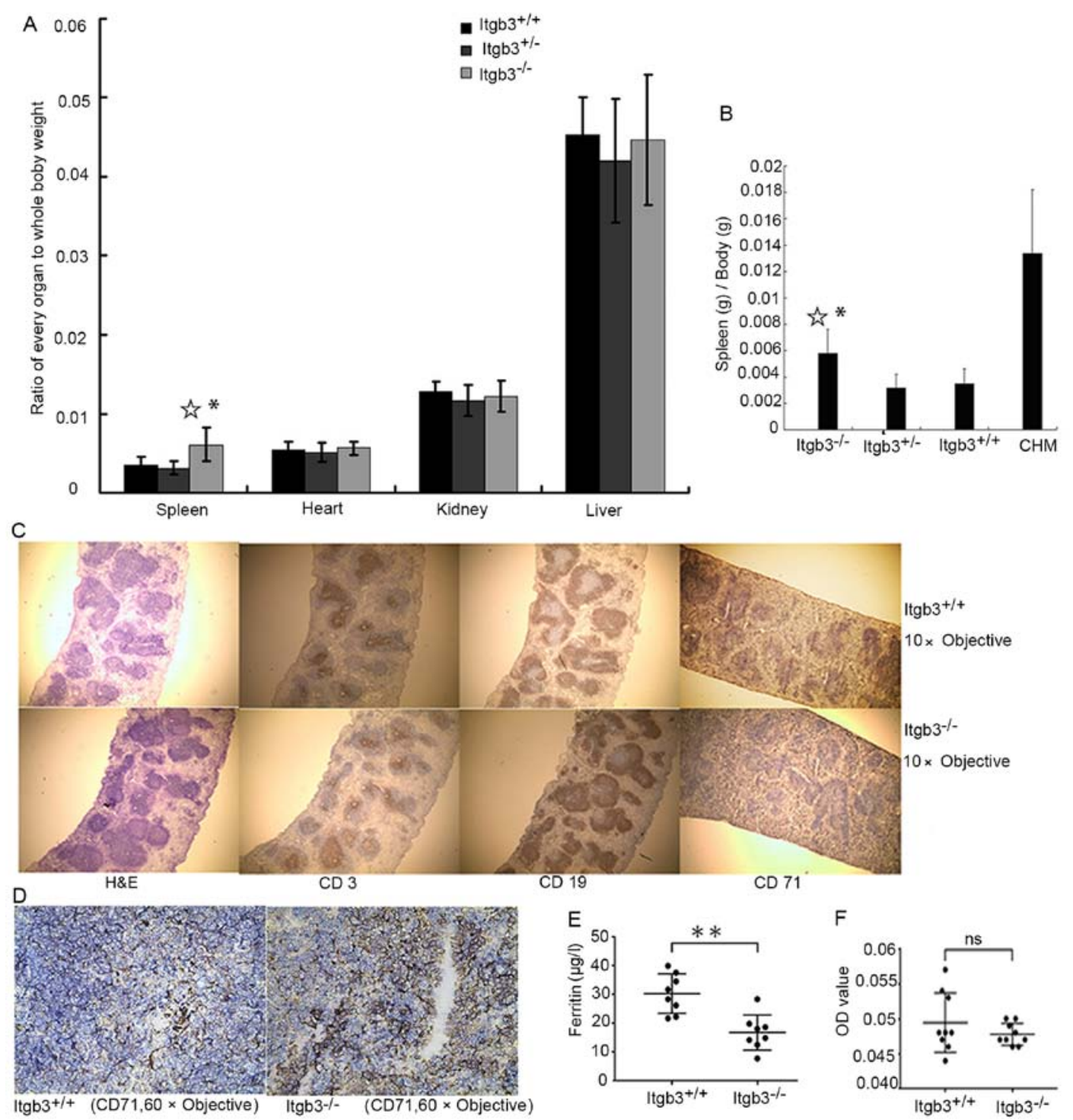

Figure 5. Spleen extramedullary hematopoiesis and iron deficiency of Itgb $3^{-/}$mice. (A) Relative ratio of each organ to whole body weight in different geno-

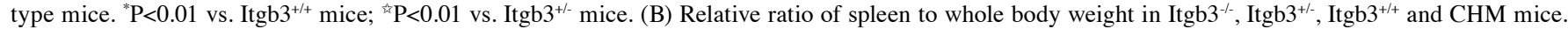
${ }^{*} \mathrm{P}<0.01$ vs. Itgb3 $3^{+/+}$mice; ${ }^{4} \mathrm{P}<0.01$ vs. Itgb3 ${ }^{+/}$mice. Immunohistochemical study of spleen biopsy from Itgb3 $3^{+/+}$, Itgb3 $3^{-/}$mice. Anti-CD3 antibody was used to label T lymphocytes, anti-CD19 antibody to label B lymphocytes and anti-CD71 antibody to label erythrocytes. Magnification (C) x100 and (D) x600 (E) Concentration of plasma ferritin in Itgb3 $3^{-/}$mice. (F) OD value of fecal occult blood in Itgb3 $3^{-\leftarrow}$ mice using ELISA. CHM, chronic hemorrhagic model; $\mathrm{H} \& \mathrm{E}$, hematoxylin and eosin; Itgb3, integrin $\beta 3$; OD, optical density; ns, not significant.

$\alpha \operatorname{IIb} \beta 3(28,29)$. This may occur because adhesion on fibrinogen wholly depends on $\alpha \operatorname{IIb} \beta 3$, whereas adhesion on collagen depends on not only $\alpha \operatorname{IIb} \beta 3$ but also $\alpha 2 \beta 1$ and GPIV. There was no significant difference in platelet adhesion to the vWF-coated surface between Itgb $3^{-/-}$mice and Itgb $3^{+/+}$mice, probably because vWF mainly binds to GPIb $\alpha$ (30). The bleeding time of Itgb3 $3^{-/}$mice was prolonged and subcutaneous bleeding was found in newborn pups

The whole blood test showed that the number of red blood cells and hemoglobin in blood from Itgb3 $3^{-/}$mice decreased compared with that in blood from $\operatorname{Itgb} 3^{+/+}$mice or $\operatorname{Itgb}^{+/-}$mice, in accordance with a previous finding (11). The peripheral blood smear from Itgb3 ${ }^{-/}$mice showed microcytic hypochromic erythrocytes. Further bone marrow smear and iron staining confirmed the proliferation of erythroblasts and iron deficiency, suggesting occurrence of iron deficiency anemia (IDA). In addition to morphology and iron staining of bone marrow, IDA has several diagnostic criteria (31), including the decreased level of ferritin and/or gastrointestinal bleeding. The plasma ferritin was tested, and it was found that the concentration of plasma ferritin in Itgb3 ${ }^{-/}$mice was lower compared with Itgb3 $3^{+/+}$mice, which fulfilled the diagnostic criteria of IDA. However, fecal occult blood test demonstrated no difference between Itgb $3^{--}$mice and $\operatorname{Itgb} 3^{+/ /}$mice, probably due to the intermittent characteristics of gastrointestinal bleeding of Itgb3 $3^{-/}$mice. In patients with GT, gastrointestinal bleeding is usually intermittent (21).

Platelet count in Itgb3 $3^{--}$mice was decreased compared with $\operatorname{Itgb} 3^{+/+}$mice or Itgb $3^{+-}$mice, although a previous study reported no significant difference in platelet count between Itgb3 ${ }^{-/}$and Itgb3 $3^{+/+}$mice (11). The hemorrhagic diathesis may be due to not only the damaged platelet function but also to the decreased platelet count. Patients with GT have normal platelet counts (32). However, although $\mathrm{Itgb}^{-/-}$mice are regarded as a model for GT, the present study found that platelet count was decreased 
in $\operatorname{Itgb} 3^{-/-}$mice. This finding suggested that $\operatorname{Itgb} 3^{-/-}$mice differ markedly from patients with GT.

Another difference that the present study found was splenomegaly, which is absent in patients with GT, even in those with IDA (32). At first, it was hypothesized that there might be an abnormality in the lymphatic immune system of Itgb3 $^{-/-}$compared with that of Itgb3 ${ }^{+/+}$mice. However, immunohistochemical analysis of spleen biopsy showed that the expression of $\mathrm{CD} 3$, a marker on the $\mathrm{T}$ cell surface and CD19, a marker on the B cell surface, did not differ between Itgb3 $^{-/}$and Itgb3 $3^{+/}$mice. Furthermore, immunohistochemical analysis of spleen biopsy showed increased expression of the erythrocyte marker, CD71, suggesting that the splenomegaly in Itgb $^{-/}$mice may be associated with extramedullary hematopoiesis. Furthermore, to identify whether extramedullary hematopoiesis is a result of bleeding-induced anemia, CHM mice were established by regular phlebotomy of $\mathrm{Itgb}^{+/+}$mice. Evident enlargement of the spleen was observed in CHM mice suggesting that the splenomegaly was a result of compensatory extramedullary hematopoiesis due to chronic blood loss $(33,34)$. These discrepancies following blood loss between humans and mice may result from species-specific differences. Additionally, there is a wide spectrum of phenotypes of patients with GT and environmental factors also contribute to these variations (32), whereas the genotype of Itgb3 $3^{-/}$mice is homogeneous and the breeding environment of mice was also unified and standardized.

Despite possessing a number of characteristics that mimic GT, such as the absence of Itgb3 and $\alpha \mathrm{IIb}$, damage of platelet function, bleeding trend and IDA, Itgb3 ${ }^{-/}$mice also displayed a number of characteristics that are absent in patients with GT, such as decreased platelet count, splenomegaly and extramedullary hematopoiesis. Therefore, as Itgb3 $3^{-/-}$mice possessed special characteristics that differed from those found in human patients with GT, and they cannot completely simulate patients with GT.

\section{Acknowledgements}

Not applicable.

\section{Funding}

The present study was funded by The National Natural Science Foundation of China (grant no. 81700130), Natural Science Foundation of Jiangsu Province of China (grant no. BK20150474), The Science and Technology Commission of Zhenjiang Municipality (grant no. SH2017006), Novo Nordisk Haemophilia Research Fund in China and Youth Medical Talents Project of 'Ke Jiao Qiang Wei' project of Jiangsu province (grant no. QNRC201684).

\section{Availability of data and materials}

The datasets used and/or analyzed during the current study are available from the corresponding author on reasonable request.

\section{Authors' contributions}

XS conceived and designed the experiments. DL, JP and TL performed the experiments. YL and MC analyzed the data. XS and DL wrote the manuscript. XS and DL were responsible for confirming the authenticity of the data. All authors read and approved the final manuscript.

\section{Ethics approval and consent to participate}

All animal procedures were approved by The Animal Ethics Committee of Jiangsu University (approval no. UJS-IACUCAP-20190307021).

\section{Patient consent for publication}

Not applicable.

\section{Competing interests}

The authors declare that they have no competing interests.

\section{References}

1. Coller BS: $\alpha \operatorname{IIb} \beta 3$ : Structure and function. J Thromb Haemost 13 (Suppl 1): S17-S25, 2015.

2. Hynes RO: Integrins: Bidirectional, allosteric signaling machines. Cell 110: 673-687, 2002.

3. Wagner CL, Mascelli MA, Neblock DS, Weisman HF, Coller BS and Jordan RE: Analysis of GPIIb/IIIa receptor number by quantification of 7E3 binding to human platelets. Blood 88: 907-914, 1996.

4. Woods VL Jr, Wolff LE and Keller DM: Resting platelets contain a substantial centrally located pool of glycoprotein IIb-IIIa complex which may be accessible to some but not other extracellular proteins. J Biol Chem 261: 15242-15251, 1986.

5. Wencel-Drake JD, Plow EF, Kunicki TJ, Woods VL, Keller DM and Ginsberg MH: Localization of internal pools of membrane glycoproteins involved in platelet adhesive responses. Am J Pathol 124: 324-334, 1986.

6. Cramer EM, Savidge GF, Vainchenker W, Berndt MC, Pidard D, Caen JP, Massé JM and Breton-Gorius J: Alpha-granule pool of glycoprotein IIb-IIIa in normal and pathologic platelets and megakaryocytes. Blood 75: 1220-1227, 1990.

7. Ginsberg MH, Du X and Plow EF: Inside-out integrin signalling. Curr Opin Cell Biol 4: 766-771, 1992.

8. Shattil SJ: Signaling through platelet integrin alpha IIb beta 3 : Inside-out, outside-in, and sideways. Thromb Haemost 82: 318-325, 1999.

9. Leclerc JR: Platelet glycoprotein IIb/IIIa antagonists: Lessons learned from clinical trials and future directions. Crit Care Med 30 (Suppl 5): S332-S340, 2002.

10. Youssefian T, Massé JM, Rendu F, Guichard J and Cramer EM: Platelet and megakaryocyte dense granules contain glycoproteins Ib and IIb-IIIa. Blood 89: 4047-4057, 1997.

11. Hodivala-Dilke KM, McHugh KP, Tsakiris DA, Rayburn H, Crowley D, Ullman-Culleré M, Ross FP, Coller BS, Teitelbaum S and Hynes RO: Beta3-integrin-deficient mice are a model for Glanzmann thrombasthenia showing placental defects and reduced survival. J Clin Invest 103: 229-238, 1999.

12. Nurden AT: Glanzmann thrombasthenia. Orphanet J Rare Dis 1: 10, 2006.

13. Feng X, Novack DV, Faccio R, Ory DS, Aya K, Boyer MI, McHugh KP, Ross FP and Teitelbaum SL: A Glanzmann's mutation in beta 3 integrin specifically impairs osteoclast function. J Clin Invest 107: 1137-1144, 2001.

14. Shi X, Yang J, Cui X, Huang J, Long Z, Zhou Y, Liu P, Tao L, Ruan Z, Xiao B, et al: Functional effect of the mutations similar to the cleavage during platelet activation at integrin $\beta 3$ cytoplasmic tail when expressed in mouse platelets. PLoS One 11: e0166136, 2016.

15. Yin H, Liu J, Li Z, Berndt MC, Lowell CA and Du X: Src family tyrosine kinase Lyn mediates VWF/GPIb-IX-induced platelet activation via the cGMP signaling pathway. Blood 112: 1139-1146, 2008. 
16. Kikuchi H, Higuchi T, Hashida Y, Taniguchi A, Kamioka M, Taguchi T, Yokoyama A, Murakami I, Fujieda M and Daibata M: Generation and characteristics of a novel 'double-hit' high grade B-cell lymphoma cell line DH-My6 with MYC/IGH and BCL6/IGH gene arrangements and potential molecular targeted therapies. Oncotarget 9: 33482-33499, 2018.

17. Fullard JF: The role of the platelet glycoprotein IIb/IIIa in thrombosis and haemostasis. Curr Pharm Des 10: 1567-1576, 2004.

18. Coller BS and Shattil SJ: The GPIIb/IIIa (integrin alphaIIbbeta3) odyssey: A technology-driven saga of a receptor with twists, turns, and even a bend. Blood 112: 3011-3025, 2008.

19. Wilcox DA,Olsen JC,Ishizawa L,Bray PF, French DL, SteeberDA, Bell WR, Griffith M and White GC II: Megakaryocyte-targeted synthesis of the integrin beta(3)-subunit results in the phenotypic correction of Glanzmann thrombasthenia. Blood 95: 3645-3651, 2000.

20. Rosenberg N, Yatuv R, Orion Y,Zivelin A, Dardik R, Peretz H and Seligsohn U: Glanzmann thrombasthenia caused by an 11.2-kb deletion in the glycoprotein IIIa (beta3) is a second mutation in Iraqi Jews that stemmed from a distinct founder. Blood 89: 3654-3662, 1997.

21. George JN, Caen JP and Nurden AT: Glanzmann's thrombasthenia: The spectrum of clinical disease. Blood 75: 1383-1395, 1990.

22. Mesquita R, Santos I and Monteiro H: Severe intestinal bleeding in a woman with glanzmann thrombasthenia. Eur J Case Rep Intern Med 5: 000796, 2018.

23. Fang J, Hodivala-Dilke K, Johnson BD, Du LM, Hynes RO, White GC II and Wilcox DA: Therapeutic expression of the platelet-specific integrin, alphaIIbbeta3, in a murine model for Glanzmann thrombasthenia. Blood 106: 2671-2679, 2005.

24. O'Toole TE, Loftus JC, Plow EF, Glass AA, Harper JR and Ginsberg MH: Efficient surface expression of platelet GPIIb-IIIa requires both subunits. Blood 74: 14-18, 1989.
25. Offermanns S: Activation of platelet function through $\mathrm{G}$ protein-coupled receptors. Circ Res 99: 1293-1304, 2006.

26. Ablooglu AJ, Kang J, Petrich BG, Ginsberg MH and Shattil SJ: Antithrombotic effects of targeting alphaIIbbeta 3 signaling in platelets. Blood 113: 3585-3592, 2009.

27. Petrich BG, Fogelstrand P, Partridge AW, Yousefi N, Ablooglu AJ, Shattil SJ and Ginsberg MH: The antithrombotic potential of selective blockade of talin-dependent integrin alpha IIb beta 3 (platelet GPIIb-IIIa) activation. J Clin Invest 117: 2250-2259, 2007.

28. Gibbins JM, Okuma M, Farndale R, Barnes M and Watson SP: Glycoprotein VI is the collagen receptor in platelets which underlies tyrosine phosphorylation of the Fc receptor gamma-chain. FEBS Lett 413: 255-259, 1997.

29. Emsley J, Knight CG, Farndale RW, Barnes MJ and Liddington RC: Structural basis of collagen recognition by integrin alpha2beta1. Cell 101: 47-56, 2000.

30. Ruggeri ZM: Von Willebrand factor, platelets and endothelial cell interactions. J Thromb Haemost 1: 1335-1342, 2003.

31. Kaushansky K, Lichtman MA and Prchal JT: Williams Hematology. 9th edition. McGraw Hill Education, New York, NY, pp628-639, 2015.

32. Kaushansky K,Lichtman MA and Prchal JT: Williams Hematology. 9th edition. McGraw Hill Education, New York, NY, p2047, 2015.

33. Elmore SA: Enhanced histopathology of the spleen. Toxicol Pathol 34: 648-655, 2006.

34. Rui Z, Ya-Nan H, Jun Y, Wen-Yu W, Bei-Bei W and Hui-Ming Z: Pathological research of splenic extramedullary hematopoie sis in aged rats. J Exp Hematol 26: 268-272, 2018.

This work is licensed under a Creative Commons Attribution-NonCommercial-NoDerivatives 4.0 International (CC BY-NC-ND 4.0) License. 